ПАТОГЕНЕТИЧНА ТЕРАПІЯ ЦЕРВІКАЛЬНОЇ ІНТРАЕПІТЕЛІАЛЬНОЇ НЕОПЛАЗІЇ II-III СТУПЕНЯ ВАЖКОСТІ

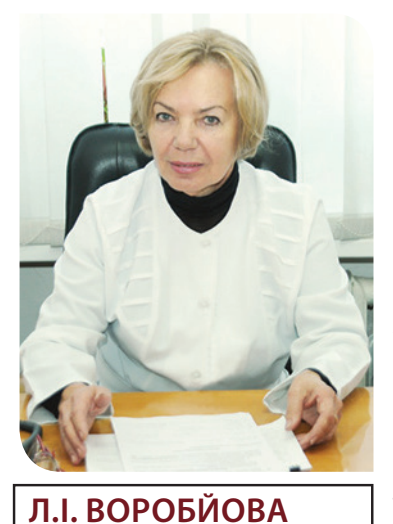

д. мед. Н., професор, зав. науково-дослідним відділенням онкогінекології Національного інституту раку (м. Київ), головний онкогінеколог М0З України

В.В. ДУНАЄВСЬКА к. мед. н., лікар онкогінеколог, Національний інститут раку, м. Київ

\section{A.М. КОШМЕРИНСЬКА}

лікар онкогінеколог,

Житомирський обласний

онкологічний диспансер

Контакти:

Дунаєвська Вікторія Вікторівна Національний інститут раку 03022, Київ, Ломоносова, 33/43 тел.: +38 (098) 0036450

e-mail: dunaevskaya80@ukr.net

Кошмеринська Аліна Миколаївна Житомирський обласний онкологічний диспансер 10002, Житомир,

Фещенка-Чопівського, 24/4 тел.: +38 (067) 1136275

e-mail:alina.koshmerinskaya@mail.ru
ВСТУП

Рак шийки матки (РШМ) є однією з найсерйозніших медичних і соціальних проблем жіночого репродуктивного здоров'я. За останні 10 років захворюваність на РШМ збільшилася на 15\%, а в осіб віком 15-39 років РШМ посідає перше місце серед усіх злоякісних пухлин у жінок [1]. На думку експертів, до 2020 р. число вперше виявлених випадків РШМ у світі зросте приблизно на 40\% [1, 2].

РШМ - одна 3 небагатьох злоякісних пухлин, яка повністю відповідає всім рекомендаціям ВООЗ щодо проведення популяційного скринінгу. Це захворювання широко розповсюджено, $\epsilon$ важливою проблемою охорони здоров'я, має добре розпізнавану преклінічну фазу і тривалий період розвитку; існують адекватні методи для верифікації діагнозу, $\epsilon$ ефективні методи лікування та доступний скринінг-тест [2].

\section{АНАЛІЗ ЛІТЕРАТУРНИХ ДАНИХ ТА \\ ПОСТАНОВКА ЗАВДАННЯ ДОСЛІДЖЕННЯ}

Наявна на сьогоднішній день сукупність епідеміологічних даних дозволяє однозначно стверджувати, що цервікальна інтраепітеліальна неоплазія (ЦІН) і РШМ належать до захворювань, обумовлених вірусною інфекцією. Головним чинником патогенезу вважається інфікування вірусом папіломи людини (ВПЛ) [1-3].

На сучасному етапі не існує лікарських засобів, що ефективно і вибірково впливають на ВПЛ. Лікувальні заходи спрямовані головним чином на ліквідацію доброякісних і передракових утворень, викликаних ВПЛ. Поряд із деструктивними методами лікування для елімінації вірусу і зменшення кількості рецидивів ЦІН нині все частіше призначаються противірусні та імунокоригуючі препарати [3, 5-7]. Тому своєчасне виявлення і усунення ЦІН $€$ основним методом профілактики її грізних ускладнень [5, 11].

Мета цього дослідження полягала в оцінці ефективності комбінації біологічно активного комплексу, до складу якого входить індол-3-карбінол і епігаллокатехін-3-галлат у поєднанні з конізацією шийки матки в лікуванні ЦІН помірного та важкого ступеня на фоні інфікування ВПЛ 16-го і 18-го типів.

Біологічно активний комплекс, до складу якого входить індол-3-карбінол і епігаллока- техін-3-галлат - Епігалін ${ }^{\circledR}$, компоненти якого містяться в овочах родини капустяних (хрестоцвітих). Він здатний:

3 блокувати естрадіолозалежну індукцію онкогена E7, різко знижуючи таким чином рівень його експресії і перешкоджаючи гормонозалежній проліферації інфікованих клітин;

- нормалізувати метаболізм естрадіолу в клітинах, інфікованих ВПЛ, перешкоджаючи утворенню канцерогенного метаболіту 16а-гідроксиестрону, який стимулює експресію онкогенів ВПЛ;

s індукувати апоптотичні процеси у ВПЛінфікованих клітинах, обумовлюючи вибіркову загибель клітин із пухлинними властивостями.

\section{МАТЕРІАЛИ І МЕТОДИ ДОСЛІДЖЕННЯ}

У дослідження увійшли 60 пацієнток із ЦІН II-III ступеня важкості, що асоційовані з ВПЛ 16/18-го типів. Дане дослідження проходило на базі Національного інституту раку в 20132015 рр. Середній вік обстежених жінок склав $29,7 \pm 2,8$ років.

Усім пацієнткам виконувався стандартний план обстежень при ЦІН II-ІІІ ступеня важкості, який включав цитологічне дослідження (Пап-тест), ВПЛ-дослідження шляхом полімеразної ланцюгової реакції (ПЛР) в режимі реального часу, просту та розширену кольпоскопію, дослідження біоценозу генітального тракту за допомогою технології Фемофлор-скрін, морфологічну верифікацію даної патології шляхом імуногістохімічного дослідження маркера проліферації Кі-67. Визначення маркера Кі-67 проводили на депарафінованих зрізах товщиною 4-5 мкм, із попереднім демаскуванням антигену у цитратному буфері $(\mathrm{pH} \mathrm{6,0)}$ в мікрохвильовій печі протягом 10 хв. Для візуалізації продуктів реакції застосовували систему EnVision. Як первинні антитіла використовували Кі-67 (клон МІB) фірми «DAKO Cytomation». Оцінку результатів імуногістохімічного забарвлення здійснювали за допомогою світлового мікроскопа (збільшення $\times 1250$, масляна імерсія). Результати імуногістохімічної реакції оцінювали напівкількісним методом шляхом підрахунку відсотка позитивно забарвлених клітин (індекс позначки), ступінь інтенсивності забарвлення оцінювали візуально. В кожному випадку аналізували від 800 до 1000 епі- 
теліальних клітин. Усім досліджуваним пацієнткам проводилося обстеження місцевого та загального імунітету. Імунологічне обстеження включало визначення кількості та субпопуляційного складу лімфоцитів (CD4, CD8, CD16) за допомогою моноклональних антитіл з обліком реакції на проточному цитофлюориметрі, а також визначення рівня циркулюючих імунних комплексів (за Дігеоном).

3 метою отримання матеріалу для морфологічної верифікації всім досліджуваним жінкам було виконано діагностичне вишкрібання стінок цервікального каналу, біопсія шийки матки, пайпель-біопсія ендометрія.

Пацієнтки були розділені на дві групи в залежності від призначеного лікування. До I групи увійшли 30 жінок, які перед хірургічним етапом лікування отримували імунотерапію за стандартною схемою та плацебо протягом 1-го міс, далі їм виконувалася конізація шийки матки. В післяопераційному періоді пацієнтки продовжували отримувати імунотерапію та плацебо впродовж 5-ти міс. В II групу увійшло також 30 пацієнток, які отримували імунотерапію за тією ж схемою з додаванням біологічно активного комплексу Епігалін ${ }^{\circledR}$ по 2 капсули двічі на добу протягом 1-го міс перед хірургічним лікуванням і далі протягом 5-ти міс після конізації шийки матки.

Оцінка ефективності лікування визначалася з урахуванням ПЛР-діагностики ВПЛ, бактеріологічного та цитологічного досліджень мазка, кольпоскопічного контролю до початку лікування та через 3, 6, 9 і 12 міс після нього, імуногістохімічного дослідження з визначенням маркеру проліферації Кі-67. Показники загального і місцевого імунітету також були включені в оцінку ефективності терапії даної патології. Обробка статистичних даних здійснювалася за допомогою програми Excel.

\section{РЕЗУЛЬТАТИ ДОСЛІДЖЕННЯ}

При цитологічному дослідженні через 3 міс після лікування ЦІН І-ІІ ступеня не було виявлено в мазках жодної з пацієнток. В подальші терміни спостереження ЦІН І-ІІ ступеня не виявлялася у 92\% пацієнток II групи в порівнянні 3 I групою, де цитологічно її не було діагностовано в 76,6\% жінок.

Протирецидивний ефект Епігаліну ${ }^{\circledR}$ пояснюється його ВПЛ-елімінуючою властивістю, що з'являється вже в ранні терміни спостереження. За даним ПЛР в режимі реального часу через 3 міс від початку лікування ВПЛ виявлявся у пацієнток II групи, які отримували комплексне лікування, В 2,2 рази рідше, ніж у групі порівняння (медикаментозна терапія без застосування Епігаліну ${ }^{\circledR}$ ).

Дія препарату була пролонгованою, оскільки через 6 міс від початку лікування (3 міс після завершення прийому Епігаліну ${ }^{\circledR}$ у у II групі були практично повністю відсутні випадки виявлення ВПЛ в слизовій оболонці цервікального каналу, а через 9 і 12 міс вірус не виявлявся зовсім. Тоді як у 53,3-26,7\% пацієнток I групи, які приймали плацебо, ДНК ВПЛ типів 16/18 реєструвались протягом року спостереження від початку лікування (табл. 1).

Зниження вірусного навантаження вочевидь вплинуло на динаміку показників активності імунної системи, що свідчить про більш ранню і повну нормалізацію під впливом
ТАБЛИЦЯ 1. ПОКАЗНИКИ ЕФЕКТИВНОСТІ ЕПІГАЛІНУ В КОМПЛЕКСНОМУ ЛІКУВАННІ ХВОРИХ ІЗ ЦІН СЕРЕДНЬОГО І ВАЖКОГО СТУПЕНЯ

\begin{tabular}{|c|c|c|c|}
\hline \multirow{2}{*}{\multicolumn{2}{|c|}{ Показники }} & \multicolumn{2}{|c|}{ Групи } \\
\hline & & $\begin{array}{c}\mathrm{I} \\
\mathrm{n}=30(50 \%)\end{array}$ & $\underset{n=30(50 \%)}{\text { II }}$ \\
\hline \multicolumn{2}{|c|}{$\begin{array}{c}\text { Середнє число ВПЛ-позитивних пацієнток } \\
\text { протягом року після лікування }\end{array}$} & $6,6 \pm 0,5^{*}$ & $2,2 \pm 0,1$ \\
\hline \multirow{4}{*}{$\begin{array}{c}\text { Кількість ВПЛ-позитивних } \\
\text { пацієнток після початку } \\
\text { лікування (\%) }\end{array}$} & Через 3 міс & $12(73)^{*}$ & $8(33,3)$ \\
\hline & Через 6 міс & $9(53,3)^{*}$ & $2(5,8)$ \\
\hline & Через 9 міс & $6(33,3)$ & - \\
\hline & Через 12 міс & $5(26,7)$ & - \\
\hline
\end{tabular}

* статистично значущі розходження ( $\leq \leq 0,05$, Х2 критерій Пірсона) у порівнянні 3 відповідними показниками в групі II

ТАБЛИЦЯ 2. ХАРАКТЕРНІ ЗМІНИ ІМУННОГО СТАТУСУ ХВОРИХ ІЗ ЦІН СЕРЕДНЬОГО І ВАЖКОГО СТУПЕНЯ ПРИ КОМПЛЕКСНОМУ ЛІКУВАННІ ЕПІГАЛІНОМ

\begin{tabular}{|c|c|c|c|}
\hline \multirow{2}{*}{\multicolumn{2}{|c|}{$\begin{array}{c}\text { Найчастіше змінювані параметри } \\
\text { імунного статусу (після початку } \\
\text { лікування) }\end{array}$}} & \multicolumn{2}{|c|}{ Групи } \\
\hline & & \multirow{2}{*}{$\begin{array}{c}\text { I } \\
\mathbf{n}=30(50 \%) \\
0,16 \pm 0,02^{*}\end{array}$} & \multirow{2}{*}{$\begin{array}{c}\text { II } \\
\mathbf{n}=\mathbf{3 0}(\mathbf{5 0 \%}) \\
0,12 \pm 0,02^{*}\end{array}$} \\
\hline \multirow{2}{*}{ До лікування } & CD16, г/л & & \\
\hline & $\mathrm{CD} 4 / \mathrm{CD} 8$ & $0,78 \pm 0,12^{*}$ & $0,76 \pm 0,11^{*}$ \\
\hline \multirow{2}{*}{$\begin{array}{l}\text { Через } 3 \text { міс } \\
\text { від початку } \\
\text { лікування }\end{array}$} & CD16, г/л & $0,18 \pm 0,04^{*}$ & $0,22 \pm 0,05$ \\
\hline & $\mathrm{CD} 4 / \mathrm{CD} 8$ & $0,85 \pm 0,12^{*}$ & $1,39 \pm 0,14$ \\
\hline \multirow{2}{*}{$\begin{array}{l}\text { Через } 6 \text { міс } \\
\text { від початку } \\
\text { лікування }\end{array}$} & CD16, г/л & $0,18 \pm 0,02^{*}$ & $0,30 \pm 0,05$ \\
\hline & $\mathrm{CD} 4 / \mathrm{CD} 8$ & $0,98 \pm 0,14^{*}$ & $1,58 \pm 0,12$ \\
\hline
\end{tabular}

* статистично значущі розходження ( $\mathrm{p} \leq 0,05$, $\mathrm{t}$-тест) в порівнянні з відповідними значеннями у донорів: $\mathrm{CD} 16=0,28 \pm 0,02$ г/л; $\mathrm{CD} 4 / \mathrm{CD} 8=1,62 \pm 0,09$

комплексної терапії із застосуванням Епігаліну ${ }^{\circledR}$ стосовно відповідних значень у групі порівняння (табл. 2). При цьому найбільш значущих змін зазнали концентрація лімфоцитів CD16 і рівень імунорегуляторного індексу CD4/CD8. У жінок, які приймали Епігалін ${ }^{\circledR}$, вони статистично значуще не відрізнялися від норми вже через 3 міс від початку лікування. У пацієнток, які отримували плацебо, нормалізації цих показників не було зареєстровано до кінця 6 міс від початку лікування.

За результатами імуногістохімічного дослідження, перед початком лікування в матеріалі вишкрібу цервікального каналу в пацієнток обох груп маркер проліферації Кі-67 за наявності ЦІН II ступеня становив від 32,3 до 35,4 (в середньому 33,7), при ЦІН ІІІ ступеня - від 52,1 до 58,7 (в середньому 55,3).

Оцінюючи маркер проліферації в матеріалі, отриманому після конізації шийки матки, в пацієнток I групи було виявлено, що при ЦІН ІІ ступеня важкості він становив від 26,3 до 28,4 (в середньому 27,1), а в пацієнток із ЦІН ІІІ ступеня важкості - від 43,7 до 47, 3 (в середньому 46,8).

У пацієнток II групи Кі-67 при ЦІН II ступеня важкості складав 14,3-18,4 (в середньому 16,1), у жінок із ЦІН ІІІ сту- 


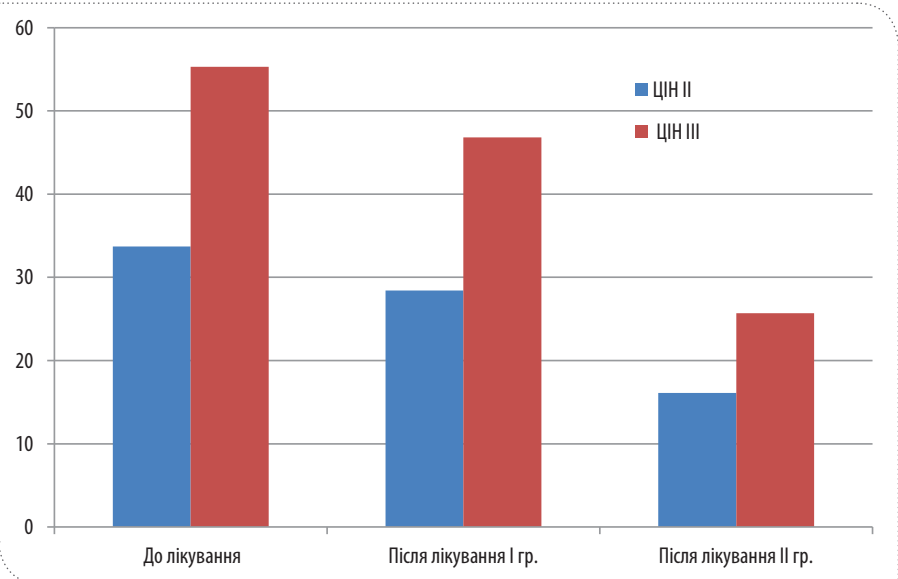

РИСУНОК. ПОРІВНЯЛЬНА ЕФЕКТИВНІСТЬ ТЕРАПІЇ ЕПІГАЛІНОМ ТА СТАНДАРТНОЇ СХЕМИ ЛІКУВАННЯ ЗА РЕЗУЛЬТАТАМИ ІМУНОГІСТОХІМІЧНОГО ДОСЛІДЖЕННЯ (МАРКЕРА ПРОЛІФЕРАЦІЇ КІ-67)

пеня важкості коливався в межах від 24,1 до 26,5 (в середньому 25,7) відповідно (рисунок).

3 урахуванням отриманих значень Кі-67 можна зробити висновок, що комбінація імунопрепарату та Епігаліну ${ }^{\circledR}$ $\epsilon$ ефективнішою для елімінації ВПЛ та профілактики рецидиву захворювання. Зокрема, при ЦІН ІІ ступеня мало місце зниження маркеру проліферації в пацієнток II групи проти I групи в 1,68 разів, при ЦІН III ступеня Кі-67 в II групі знизився в 1,82 рази у порівнянні з I групою.

Загалом показник Кі-67 у пацієнток I групи знизився на 27,1\% при ЦІН ІІ ступеня та на 15,4\% при ЦІН ІІІ ступеня, у жінок 3 II групи - на 52,2\% та 53,5\% відповідно.

Призначене лікування пацієнтки перенесли без ускладнень. Алергічних реакцій на біологічно активний комплекс за час лікування не відзначено.

\section{ВИСНОВОК}

Проведене дослідження свідчить про ефективність препарату Епігалін ${ }^{\circledR}$ у комплексному лікуванні ЦІН II-III ступеня важкості. Епігалін ${ }^{\circledR}$ перешкоджає проліферації інфікованих клітин, індукує апоптотичні процеси у ВПЛ-інфікованих, позитивно впливає на активність місцевої та системної імунної відповіді. Своєчасно проведене патогномонічне лікування $\epsilon$ ефективною профілактикою розвитку злоякісних процесів шийки матки.

\section{ЛИТЕРАTУPA/REFERENCES}

1. Бебнева, Т.Н.

Некоторые клинические аспекты папилломавирусной инфекции / Т.Н. Бебнева // Гинекология. - 2007. - Т. 9, № 1. - C. 20-24.

Bebneva, T.N.

"Some clinical aspects of HPV infection." Gynecology, 1 (Vol. 9) (2007): 20-24.

2. Прилепская, В.Н.

Папилломавирусная инфекция: диагностика, лечение и профилактика / В.Н. Прилепская, С.И. Роговская,

Н.И. Кондриков, Г.Т. Сухих. - М.: МЕДпресс-информ. 2007. - $32 \mathrm{c}$.

Prilepskaya, V.N., Rogovskaya, S.I., Kondrikov, N.I., Sukhyh, G.T. Human papillomavirus infection: diagnosis, treatment and prevention. Moscow. MEDpress-inform (2007): 32 p.

3. Роговская, С.И.

Новые технологии в профилактике рака шейки матки / С.И. Роговская, В.Н. Прилепская // Гинекология. 2008. - T. 10, № 1. - C. 4-7.

Rogovskaya, S.I., Prilepskaya, V.N.

"New technologies in cervical cancer prevention." Gynecology, 1 (Vol. 10) (2008): 4-7.

4. Роговская, С.И.

Папилломавирусная инфекция у женщин и патология шейки матки: В помощь практикующему врачу /

С.И. Роговская. — 2-е изд. - М.: ГЭОТАР-Медиа. -

2008. - 192 c.

Rogovskaya, S.I.

HPV infection in women, and pathology of the cervix: To help the practitioner physician. 2nd ed. Moscow. GEOTAR-Media (2008): $192 p$.

\section{5. Сухих, Г.Т.}

Новые скрининговые технологии в профилактике рака шейки матки / Г.Т. Сухих, В.Н. Прилепская // Материалы Международной научно-практической конференции «Профилактика рака шейки матки: взгляд в будущее». M., 2008. - C. 110-111.

Sukhyh, G.T., Prilepskaya, V.N.

New screening technology in cervical cancer prevention // Materials of the International scientific and practical conference "Prevention of Cervical Cancer: A look into the future." Moscow (2008): 110-111.
6. Яковлева, В.А.

Структура поверхности эпителиальных клеток шейки матки, инфицированных вирусом папилломы человека: дис. ... канд. биол. наук / В.А. Яковлева. - М., 2009. $108 c$.

Yakovleva, V.A.

The surface structure of cervical epithelial cells infected with the human papilloma virus: dissertation on the degree of candidate of biological sciences. Moscow (2009): 108 p.

\section{7. Шперлинг, Н.В.}

Опыт применения индинола при рецидивирующей папилломавирусной инфекции гениталий / Н.В. Шперлинг, А.И. Венгеровский, 0.А. Персидская, И.А. Шперлинг // Клинические дерматология и венерология. - 2009. № 2. - C. 32-36.

Sperling, N.V., Vengerovsky, A.I., Persidskaya, 0.A., Sperling, I.A. "Experience of the indinol use for recurrent genital HPV infection." Clinical Dermatology and Venereology, 2 (2009): 32-36.

8. Ашрафян, Л.А., Киселев В.И.

Опухоли репродуктивных органов (этиология и

патогенез). - М., 2007. - 208 c.

Ashrafyan, L.A., Kiselev, V.I.

Tumors of the reproductive organs (etiology and pathogenesis). Moscow (2007): $208 p$.

9. Киселев В.И., МуйжнекЕ.Л.

Молекулярные механизмы развития дисплазии шейки матки: новые знания - новые возможности. — М., 2012. Kiselev, V.I., Muyzhnek, E.L.

Molecular mechanisms of the cervical dysplasia development: new knowledge - new opportunities. Moscow (2012).

10. Chung, S.H., Wiedmeyer, K., Shai, A., Korach, K.S., Lambert, P.F. "Requirement for estrogen receptor a in a mouse model for human papillomavirus-associated cervical cancer." Cancer Res, 68(23) (2008): 9928-9934.

11. De Vuyst, H., Clifford, G., Li, N., Franceschi, S. "HPV infection in Europe." Eur J Cancer, 45(15) (2009): 2632-2633.

12. Fang, M.Z., Wang, Y., Ai, N., Hou, Z., Sun, Y., Lu H., et al. "Tea polyphenol (-)-epigallocatechin-3-gallate inhibits DNA methyltransferase and reactivates methylation-silenced genes in cancer cell lines." Cancer Res, 63(22) (2003): 7563-7570.
13. Городецкая, С.Б., Свешников, П.Г., Бударина, С.О. и др. Значение исследования уровня экспрессии онкобелка Е7 ВПЧ 16-го и 18-го типов в цервикальном материале в диагностике неопластических образований шейки матки / С.Б. Городецкая, П.Г. Свешников,

С.О. Бударина и др. // Молекулярная медицина. 2010. — № 5 .

Gorodetskaya, S.B., Sveshnikov, P.G., Budarina, S.0., et al. "The value of the study of the level expression of HPV-16 and -18 types E7 oncoprotein in cervical material in the diagnosis of neoplastic formations of the cervix." Molecular Medicine, 5(2010).

14. Подистов, Ю.И., Лактионов, К.П., Петровичев, Н.Н., Брюзгин, В.B.

Эпителиальные дисплазии шейки матки (диагностика и лечение). - М., 2006. - 133 c.

Podistov, Y.I., Laktionov, K.P., Petrovichev, N.N., Bryuzgin, V.V. Epithelial dysplasia of the cervix (diagnosis and treatment). Moscow (2006): 133 p.

15. Jabbar, S.F., Abrams, L., Glick, A., Lambert, P.F. "Persistent of high-grade cervical dysplasia and cervical cancer requires the continuous expression of the human papilloma virus type 16 E7 oncogene." Cancer Res, 69(10) (2009): 4407-4414.

16. He, H.J., Pan, L.Y. Huang, H.F., Lang, J.H.

"Clinical analysis of the effect of cervical conization in fertility and pregnancy outcome." Zhonghua Fu Chan Ke Za Zhi, 42(8) (2007): 515-521.

17. Qi, M., Anderson, A.E., Chen, D.Z., Sun, S., Auborn, K.J. "Indole-3-carbinol prevents PTEN loss in cervical cancer in vivo." Mol Med, 11(2005): 59-63.

18. Соколовский, Е.В.

Иммуномодулирующая терапия папилломавирусной инфекции / Е.В. Соколовский, А.В. Игнатовский // Вопросы гинекологии, акушерства и перинатологии. - 2005. T. 4, № 4. - C. 27-30. Sokolovsky, E.V., Ignatovsky, A.B.

"Immunomodulatory therapy of human papillomavirus infection." Questions of Gynecology, Obstetrics and Perinatology, 4 (Vol. 4) (2005): 27-30. 
19. Фролова, И.И.

Цервикальные интраэпителиальные неоплазии и дискератозы шейки матки / И.И. Фролова, И.И. Бабиченко, Г.М. Местергази. — М.: Династия. — 2004. — 88 c. Frolova, I.I., Babichenko, I.I., Mestergazi, G.M.

Cervical intraepithelial neoplasia and cervical dyskeratosis. Moscow. Dynasty (2004): 88 p.

20. Шипицына, Е.В.

Диагностика папилломавирусной инфекции в скрининге рака шейки матки / Е.В. Шипицына, Е.А. Золотоверхая, Е.С. Юшманова, А.М. Савичева // Журнал акушерства и женских болезней. - 2007. - Т. 56. - C. 72-75.

Shipitsyna, E.B., Zolotoverkhaya, E.A., Yushmanova, E.S., Savicheva, A.M.

"Diagnosis of HPV infection in cervical cancer screening." Journal of Obstetrics and Gynecological Diseases, 56(2007):

72-75.

21. Телетаева, Г.М.

Цитокины и противоопухолевый иммунитет /

Г.М. Телетаева // Практическая онкология. — 2007. —

T. 8, № 4. - C. 211-218.

Teletaeva, G.M.

"Cytokines and antitumor immunity." Practical Oncology,

4 (Vol. 8) (2007): 211-218.
22. Bottley, G., Watherston, O.G., Hiew, Y.L., et al.

"High-risk human papillomavirus E7 expression reduces cellsurface MHC class I molecules and increases susceptibility to natural killer cells." Oncogene, 12 (Vol. 27) (2008): 1794-1799.

23. Brinton, L.A., Reeves, W.C., Brenes, M.M., et al. "Prity as a risk factor for cervical cancer." Am J Epidemiol, 130(1999): 486-496.

24. Broom, J.K., Lew, A.M., Azukizawa, H., et al. "Antigen-specific CD4 cells assist CD8 T-effector cells in eliminating keratinocytes."J Invest Dermatol, 6 (Vol. 130) (2010): 1581-1589.

25. Brown, D.R., Legge, D., Qadadri, B.

"Distribution of human papillomavirus types in cervicovaginal washings from women evaluated in a sexually transmitted diseases clinic." Sex Transm Dis, 29(2002): 763-768.

26. Brown, D.R., Shew, M.L., Qadadri, B., et al.

"A longitudinal study of genital human papillomavirus

infection in a cohort of closely followed adolescent women."

J Infect Dis, 191(2005): 182

27. Bruni, L., M. Diaz, M., Castellsague, X.

"Cervical human papillomavirus prevalence in 5 continents: metaanalysis of 1 million women with normal cytological findings." J Infect Dis, 12 (Vol. 202) (2010): 1789-1799.
28. Campo, M.S., Graham, S.V., Cortese, M.S., et al.

"HPV-16 E5 down-regulates expression of surface HLA class I and reduces recognition by CD8 T cells." Virology, 1 (Vol. 407) (2010): 137-142.

29. Castellsague, X., Bosch, F.X., Munoz, N.

"Environmental co-factors in HPV carcinogenesis."Virus Res, 89(2002): 191-199.

30. Castle, P.E., Schiffman, M., Gravitt, P.E.

"Comparisons of HPV DNA detection by MY09/11 PCR methods." J Med Virol, 3 (Vol. 68) (2002): 417-423.

31. Castle, P.E., Schiffman, M., Wheeler, C.M., et. al.

"Human, papillomavirus genotypes in cervical intraepithelial neoplasia grade 3." Cancer Epidemiol Biomarkers Prev, 7 (Vol.

19) (2010): 1675-1681. 巴p

\section{ПАТОГЕНЕТИЧНА ТЕРАПІЯ ЦЕРВІКАЛЬНОӦ ІНТРАЕПІТЕЛІАЛЬНОӦ НЕОПЛАЗІЇ ІІ-ІІІ СТУПЕНЯ ВАЖКОСТІ}

Л.І. Воробйова, д. мед. н., професор, зав. науково-дослідним відділенням онкогінекології Національного інституту раку (м. Київ), головний онкогінеколог МОзУкраїни

В.В. Дунаєвська, к. мед. н., лікар онкогінеколог, Національний інститут раку, м. Київ

А.М. Кошмеринська, лікар онкогінеколог, Житомирський обласний онкологічний диспансер

Вторинна профілактика цервікального раку включає виявлення і лікування передракових захворювань, до яких відносять цервікальну інтраепітеліальну неоплазію III I III ступеня важкості, атипову лейкоплакію шийки матки. В 98\% дана патологія асоційована з вірусом папіломи людини. Традиційні хірургічні методи лікування цервікальних інтраепітеліальних неоплазій не завжди приводять до елімінації вірусу, що в свою чергу не може повністю виключити можливість рецидиву. У статті наведені дані літератури та власні спостереження про можливості патогенетичної терапії в комплексному лікуванні неоплазій. Підкреслюється, що застосування противірусних та імунних препаратів, біологічно активних комплексів у складі лікувальних заходів дозволяють домогтися вищої елімінації вірусу та профілактувати рецидиви в порівнянні із суто хірургічними методами лікування.

Ключові слова: вірус папіломи людини, рак шийки матки, індол-3-карбінол, цервікальна інтраепітеліальна неоплазія, Епігалін .

\section{ПАТОГЕНЕТИЧЕСКАЯ ТЕРАПИЯ ЦЕРВИКАЛЬНОЙ ИНТРАЭПИТЕЛИАЛЬНОЙ НЕОПЛАЗИИ ІІ-ІІІ СТЕПЕНИ ТЯЖЕСТИ}

Л.И. Воробьева, д. мед. н., профессор, зав. научно-исследовательским отделением онкогинекологии Национального института рака (г. Киев), главный онкогинеколог МЗ Украины

B.В. Дунаевская, к. мед. н., врач онкогинеколог, Национальный институт рака, г. Киев

А.М. Кошмеринская, врач онкогинеколог, Житомирский областной онкологический диспансер

Вторичная профилактика цервикального рака включает выявление и лечение предраковых заболеваний, к которым относится цервикальная интраэпителиальная неоплазия II и III степени тяжести, атипическая лейкоплакия шейки матки. В 98\% данная патология ассоциирована с вирусом папилломы человека. Традиционные хирургические методы лечения цервикальной интраэпителиальной неоплазии не всегда приводят к элиминации вируса, что в свою очередь не может полностью исключить возможность рецидива. В статье приведены данные литературы и собственные наблюдения о возможности патогенетической терапии в комплексном лечении неоплазий. Подчеркивается, что применение противовирусных и иммунных препаратов, биологически активных комплексов в составе лечебных мероприятий позволяют добиться более высокой элиминации вируса и профилактировать рецидивы по сравнению с сугубо хирургическими методами лечения.

Ключевые слова: вирус папилломы человека, рак шейки матки, индол-З-карбинол, цервикальная интраэпителиальная неоплазия, Эпигалин.

\section{PATHOGENETIC THERAPY OF CERVICAL INTRAEPITHELIAL NEOPLASIA II-III}

L.I. Vorobiova, MD, head of the Scientific and Research Department of Gynecologic Oncology, National Cancer Institute (Kyiv), Chief oncogynecologist of the Ministry of Health of Ukraine V.V. Dunaievska, PhD, oncogynecologist, National Cancer Institute, Kyiv

A.M. Koshmerynska, oncogynecologist, Zhytomyr Regional Oncology Center

The secondary prevention of cervical cancer include detection and treatment of preinvasive forms of the disease, which includes cervical intraepithelial neoplasia and atypical cervix leucoplachia. $98 \%$ cases of this pathology are associated with human papillomavirus. Traditional surgical methods of treatment of cervical intraepithelial neoplasia do not always lead to the elimination of the virus, that cannot completely exclude the possibility of recurrence. The article shows the literature data and own observations about the possibility of drug therapy in complex therapy of neoplasia. It is accentuated that the using of antiviral and immune drugs, biologically active complexes consisting of medical actions can achieve higher efficiency in comparison with surgical methods.

Keywords: human papillomavirus, cervical cancer, antiviral drugs, indole-3-carbinol, cervical intraepithelial neoplasia, Epigalin . 